Д.В. Прочухан

Харківський комп'ютерно-технологічний фаховий коледж Національного технічного університету “Харківський політехнічний інститут”, Харків

\title{
НЕЙРОМЕРЕЖЕВЕ МОДЕЛЮВАННЯ В РЕАЛІЗАЦІЇ СИСТЕМИ ВИЗНАЧЕННЯ ПРАВИЛЬНОСТІ НОСІННЯ МЕДИЧНОЇ МАСКИ
}

\begin{abstract}
Розглянуто актуальну проблему визначення правильності одягнення медичної маски у людини. Для ії вирішення запропоновано побудування моделі з використанням штучного інтелекту. Розглянуто механізм класифікації та обробки вхідних даних. Розроблено структуру згорткової нейронної мережі у вигляді моделі послідовної реалізації шарів згортки, агрегування, повного зв'язку. Обтрунтовано дочільність використання функиії ReLU для активачії вузлів. Застосовано метод Dropout для запобігання перенавчанню нейронної мережі. Вихідний шар реалізовано у вигляді одного нейрону з використанням функції активації сигмоїда. Оптимізація згорткової нейронної мережі здійснена методом стохастичного градієнтного спуску. Використано метод зворотного поширення помилки для навчання нейронної мережі. Розроблено програмний додаток на мові програмування Pуthon. Використано бібліотеку Кегаs для забезпечення точності, правильності, повноти побудованої моделі. Проведено компіляцію з використанням бінарної перехресної ентропії в якості иільової функиї. За допомогою розробленого додатку проведено ефективне навчання згорткової нейронної мережі на тестових вхідних зображеннях. Зважаючи на значні вимоги до апаратного забезпечення і програмних ресурсів, цей процес було здійснено під керуванням операційної системи Linux. Обмежена кількість періодів навчання забезпечила зменшення підсумкового часу навчання. Здійснено перевірку побудованої системи на контрольній множині. Отримано високі показники розпізнавання зображень. Працездатність програмного додатку перевірена з використанням різної апаратної $i$ програмної конфігурації. Розроблена система може бути використані у галузях, які потребують контролю виконання правил безпеки під час пандемії.
\end{abstract}

Ключові слова: згорткові нейронні мережі, моделювання, итучний інтелект, класифікація.

\section{Вступ}

Постановка проблеми. В 2019-2021 роках пандемія коронавірусу призвела до смерті багатьох людей, значного погіршення соціальної та економічної ситуації в світі. Не зважаючи на певні успіхи вчених у створенні вакцини від хвороби, у суспільстві залишається достатньо високий рівень тривоги і занепокоєння подальшим майбутнім. До пандемії тільки лікарі і окремі люди застосовували медичні маски для захисту свого здоров'я. В сучасних реаліях Всесвітня організація охорони здоров'я рекомендує носіння захисної маски для зниження ризику передачі вірусу, забезпечення відчуття захисту. В роботах [1-2] обгрунтовано зменшення швидкості розповсюдження хвороби у разі дотримання цієї рекомендації. Тому актуальною проблемою є відстеження наявності медичної маски у людей і визначення правильності ऑï носіння. Розв'язання цієї задачі засобами штучного інтелекту є більш ефективним, ніж залучення людських ресурсів. Навчена нейронна мережа і програмний додаток дозволяють автоматизувати процеси забезпечення безпеки людського життя. В нашому дослідженні необхідно віднести вхідне зображення з певним набором властивостей до одного $з$ двох класів: правильне носіння маски і неправильне. Для ефективного розв'язання задачі треба розробити топологію нейронної мережі
3 певними елементами та вузлами, задати найбільш ефективні параметри. На наступному кроці під час навчання мережі доцільно обрати метод зворотного поширення помилки. Вибір вагових коефіцієнтів та подальшу оптимізацію навченої нейронної мережі доцільно провести методом стохастичного градієнтного спуску. Реалізацію розробленої моделі необхідно здійснити, розробивши додаток на мові програмування Python.

Аналіз останніх досліджень і публікацій. Практика використання нейронних мереж бурхливо розвивається завдяки успішному використанню методів глибокого навчання. Мережі, побудовані за допомогою наведених засобів, за показниками отриманої точності перевершили свої попередні аналоги. Ефективним механізмом вирішення завдань $є$ використання згорткових нейронних мереж (3НМ) [3-4]. Наразі найчастіше використовується архітектура ЗНМ, що містить послідовність згорткових, субдискретизуючих та шарів повного з'єднання. Однією з головних переваг згорткових нейронних мереж $є$ мінімізація інформації, що міститься на вході. При обробці вхідних зображень передбачається, що вони розподіляються за певними класами. Методи машинного навчання дозволили проводити діагностику і прогнозування поширення Covid. Завдяки використанню згорткових нейронних 
мереж в галузі машинного навчання було розв'язано низку задач розпізнавання зображень [5-6]. Переважна більшість робіт присвячена розпізнаванню обличчя і перевірки особистості. Зважаючи на основну ціль дослідження, звернемо увагу на наукові роботи зарубіжних вчених по визначенню наявності медичної маски. В дослідженні [7] розроблена модель згорткової нейронної мережі, яка дозволяє визначити наявність хірургічної маски і правильність пї надягання під час роботи в операційній кімнаті 3 точністю 95\%. В роботі [8] було запропоновано розділити всі зображення на 3 категорії: “правильне носіння маски” для обличчя, “неправильне носіння маски для обличчя" та “відсутність маски для обличчя". Ідентифікацію маски проведено за допомогою мережі класифікації SRCNet i досягнуто точність $98,7 \%$. В роботі [9] для розпізнавання маски використано метод аналізу головних компонентів. Для зображень без маски точність розпізнавання склала $96,25 \%$, але для обличчя 3 маскою точність зменшилася до $68,75 \%$. В роботі [10] представлено метод сегментування для виявлення маски на будь-якому вхідному зображенні довільного розміру. Використано архітектуру згорткової нейронної мережі VGG16 і набір даних "Multi Parsing Human Dataset". До переваг розробленої моделі слід віднести можливість розпізнавання кількох масок на зображенні. Отримано точність розпізнавання 93,884\%. Поставлена проблема майже не висвітлена у вітчизняних наукових роботах. Тому для української науки проведене дослідження інноваційне. У порівнянні з зарубіжними роботами в цій галузі новизна буде полягати у збільшенні розмірності карт ознак, що забезпечить оптимізацію моделювання згорткової нейронної мережі. Тому розроблений в подальшому додаток буде мати більш низькі системні вимоги, при цьому забезпечуючи достатньо високу точність розпізнавання.

Мета статті - висвітлення методики побудування згоркової нейронної мережі, особливостей розробки програмного забезпечення для задачі визначення правильності носіння медичної маски.

\section{Виклад основного матеріалу}

Для проведення нашого дослідження і вирішення задачі класифікації спочатку визначимо певні критерії, за якими будемо відносити зображення до одного $з$ класів - правильне або неправильне носіння медичної маски. На рис. 1 представлено приклад правильно одягнутої маски. 3 наведеного рисунку зробимо висновок, що критеріями правильно одягнутої медичної маски може слугувати покрита тканиною площина обличчя, що містить ніс, рот, підборіддя.

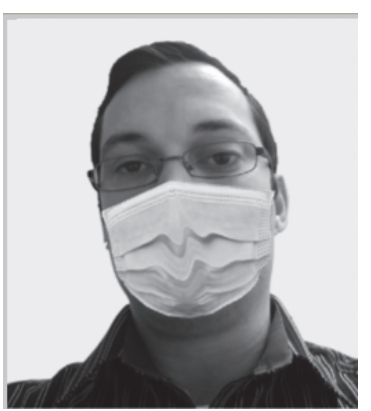

Рис. 1. Приклад правильного носіння маски Джерело: розроблено автором за даними [11, С. 4].

Ця площина, що визначається точками 1-12, представлена на рис. 2.
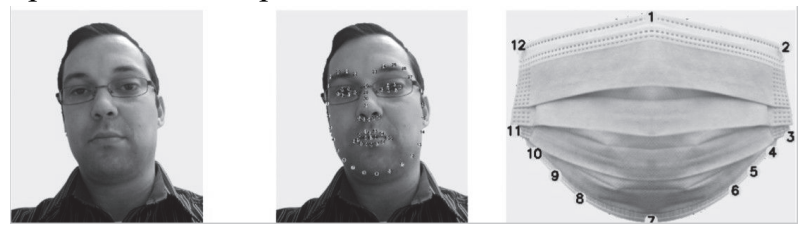

Рис. 2. Площина обличчя з правильно одягнутою маскою

Джерело: розроблено автором за даними [11, С. 4].

Маска, що носиться неправильно, не прикриває ніс, рот або підборіддя. Приклади неправильного одягання маски представлено на рис. 3.
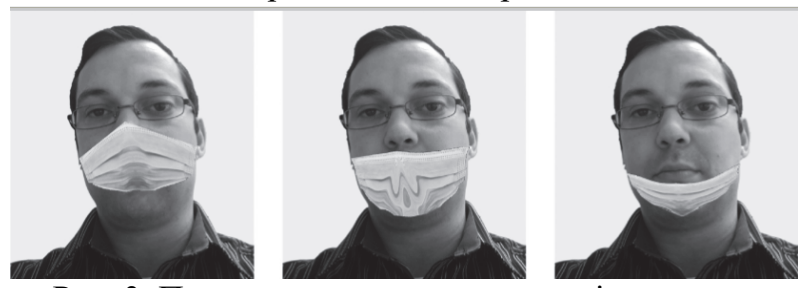

Рис. 3. Приклади неправильного носіння маски Джерело: розроблено автором за даними [11, С. 5].

В якості вихідних зображень було розглянуто набір даних, запропонованих в роботі [11]. Вказаний набір даних містить 25000 зображень. 12500 зображень містять приклади 3 правильним носінням маски. На рис. 4 наведено фрагмент набору даних, що містить зображення з правильно одягнутою маскою.

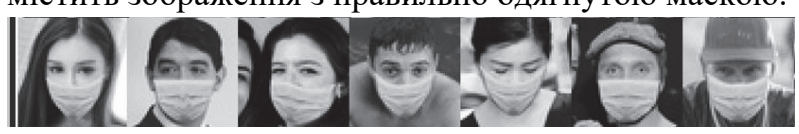

Рис. 4. Фрагмент набору даних 3 правильним носінням маски

Джерело: розроблено автором за даними [11, С. 3].

12500 зображень 3 набору даних містять приклади 3 неправильним носінням маски. Фрагмент такого типу зображень представлено на рис. 5.

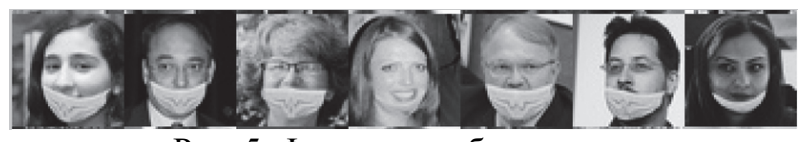

Рис. 5. Фрагмент набору даних

3 неправильним носінням маски

Джерело: розроблено автором за даними [11, С. 3].

Для проведення контролю кожен $з$ двох наборів даних було розділено на навчальну і тестову мно- 
жину Навчальний набір склав 10000 зображень 3 правильно одягненою маскою і 10000 з неправильно одягненою маскою, тобто для процесу навчання використано 80\% всіх зображень. Перевірочна множина відповідно склала 2500 зображень 3 кожного набору.

В якості алгоритму для розв'язання поставленого завдання обрано модель згорткової нейронної мережі (ЗНМ). ЗНМ сприймає та обробляє вхідні зображення у вигляді тензорів. Нейронна мережа має високу здатність до навчання за рахунок меншої кількості параметрів та зв'язків. В ЗНМ відсутні наступні недоліки традиційних мереж: складність моделі, нестійкість до змін у зображеннях, нездатність до врахування топології вхідного зображення. Перелічимо парадигми ЗНМ, які усувають наведені недоліки. Згорткова нейронна мережа виконує локальну обробку значень на прихованих рівнях. Кожен 3 рівнів поділений на частини, які можуть сприймати лише дані попереднього рівня. Ці дані знаходяться в маленькій області, яка має назву локальне рецептивне поле. ЗНМ, використовуючи механізм локальних рецептивних полів, визначає елементи та ознаки вхідного зображення. Концепція спільних ваг передбачає, що для великої кількості зв'язків використовується невеликий набір ваг. Механізм субдискретизації дозволяє зменшувати розмірність вхідних даних. Модель ЗНМ складається з вхідного шару, прихованих шарів, вихідного шару. Приховані шари містять згорткові, агрегувальні та повнозв'язні шари.

Одним з головних елементів ЗНМ є згорткові шари, у яких до даних з попереднього шару застосовується операція згортки. Згортка - це математична операція, яка за допомогою дії ядра згортки $K$ (детектора ознак) на вхідне зображення у вигляді тензора $X$ отримує як результат карту ознак $m$. Кожний детектор ознак складається з визначеної кількості фільтрів. Кожний 3 фільтрів є тензором параметрів 3 розмірністю, яка дозволяє покривати невелику частину зображення в ширину та висоту, але при цьому обов'язково відповідає розмірності в глибину. Кількість фільтрів відповідає кількості карт ознак, яка визначає глибину вихідних даних. В ході навчання фільтри набувають можливості визначати ознаки зображення, які й групуються в карти ознак. Кожен фільтр відповідає за створення однієї карти ознак. Карта ознак формується завдяки тому, що фільтр переміщується зображенням та визначає ознаки для сусідніх рецептивних полів. Не зважаючи на малі розміри, кожен фільтр проходить по всій глибині вхідного об'єму. Під час цього процесу складається двовимірна активаційна карта. Таким чином, ЗНМ обробляє набір фільтрів у шарах згортки. Цей процес сприяє формуванню карти ознак для кожного 3 фільтрів. Відносне положення ознак одна відносно одної залишається сталим. Властивості зображення зберігаються. Функція створення детекторів ознак для згорткового шару має наступний вигляд:

$$
M(i, j)=(K * X)(i, j)=\sum_{m} \sum_{n} K(m, n) X(i-m, j-n),(1)
$$

де $M(i, j)$ - елемент карти ознак $з$ координатами $i$ та $j$

$X$ - вхідне зображення і передавальної антен відповідно;

$K$ - детектор ознак.

Розмірність карти ознак може бути обчислена за наступною формулою (2):

$$
d_{m}=\frac{d_{x}-f+2 * p}{s+1},
$$

де $d_{m}$ - розмірність карт ознак;

$d_{x}$ - відмовна розмірність вхідних даних;

$f$ - розмірність фільтрів;

$p$ - відступ;

$s$ - розмір кроку обходження.

Після застосування фільтрів виконується додавання зсуву, який також є одним з параметрів мережі. Загальний процес перетворень у згортковому шарі може бути описаний наступним рівнянням:

$$
y=f(w * x+b),
$$

де $y$ - вихідний результат обчислень на згортковому шарі;

$$
\begin{aligned}
& f \text { - функція активації; } \\
& w \text { - детектор ознак; } \\
& x \text { - вихідні дані; } \\
& b \text { - зсув. }
\end{aligned}
$$

Агрегувальні або шари субдискретизації є одним 3 основних структурних елементів ЗНМ, як і згорткові шари. Агрегувальні шари включаються в модель для виконання завдання зменшення розміру вхідної карти ознак. Це призводить до зменшення кількості параметрів мережі та обчислень загалом. Ще однією перевагою використання агрегувальних шарів є контроль процесу перенавчання. Максимізаційне агрегування (англ. Max Pooling), що використовує максимальне значення 3 кожного 3 кластерів нейронів попереднього шару, може бути представлено у вигляді формули (4):

$$
p(i, j)=\max (x(i-m, j-n)),
$$

де $p(i, j)$ - значення елементу поточного рівня 3 координатами $i$ та $j$;

$x$ - вхідні дані з попередніх рівнів;

$m, n$-розмірність рецептивного поля.

Найчастіше використовується шар 3 фільтрами розміру $2 \times 2$ і кроком 2 . Шар 3 наведеними парамет- 
рами знижує дискретизацію кожного зрізу глибини входу в 2 рази як по ширині, так і по висоті. При використанні цього типу агрегування вся карта ознак розподіляться на комірки розміром 2 на 2. Серед них відбувається вибір максимального за значенням. Найчастіше використовується шар з фільтрами розміру $2 \times 2$ з кроком 2 . Подібний шар знижує дискретизацію кожного зрізу глибини входу в 2 рази як по ширині, так і по висоті, відкидаючи при цьому $75 \%$ активації. Кожна операція в цьому випадку буде вибирати максимальне значення з 4 чисел.

У шарах згортки і агрегування в середині мережі до всіх значень входу застосовується нелінійна функція активації ReLU, після чого результат подається на вихід. Використання наведеної функції робить навчання більш швидшим завдяки простому градієнту і ефективнішим через нульову реакцію на негативні значення аргументу. Графік ReLU представлено на рис. 6.

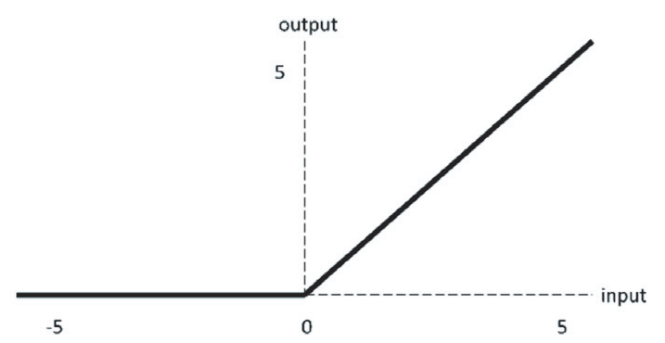

Рис. 6. Графік функції ReLU

Джерело: розроблено автором.

Однією $з$ проблем при побудуванні ЗНМ є перенавчання. Перенавчання проявляється у тому, що створена модель починає пояснювати тільки приклади 3 навчальної вибірки, адаптуючись до навчальних прикладів, замість того щоб вчитися класифікувати приклади, які не брали участі в навчанні (втрачаючи здатність до узагальнення). Для розв'язання цієї проблеми застосовується шар Dropout [12]. Запобігання перенавчанню здійснюється шляхом встановлення вихідного сигналу нейрона в значення нуль 3 ймовірністю $p$. Виключені нейрони не вносять свій внесок в процес навчання ні на одному з етапів алгоритму. Ймовірність виключення кожного нейрона однакова. При застосуванні цього засобу навчання однієї нейронної мережі замінюється навчанням декількох нейронних мереж, після чого проводиться усереднення результатів.

Повнозв'язний шар є не менш важливим за попередні типі шарів в ЗНМ. Даний шар являє собою звичайний багатошаровий перцептрон, метою якого $€$ класифікація. Він моделює складну нелінійну функцію, оптимізація якої покращує якість розпізнавання. Нейрони кожної карти попереднього підвибіркового шару пов'язані з одним нейроном прихованого шару. Таким чином, число нейронів прихованого шару дорівнює числу карт підвибіркового ша- ру. Однак зв'язки можуть бути не обов'язково такими. Наприклад, тільки частина нейронів будь-якої $з$ карт підвибіркового шару може бути пов'язана 3 першим нейроном прихованого шару, а частина, що залишилася 3 другим, або всі нейрони першої карти пов'язані з нейронами першого і другого прихованого шару. Як і в звичайних нейромережах, в повнозв'язному шарі нейрони мають повні сполуки з усіма активаціями в попередньому шарі. Їх активації можуть бути обчислені за допомогою множення матриць, що супроводжується зміщенням.

Відмінності між повнозв'язними і згортковими шарами полягають у тому, що нейрони шару згортки з'єднані тільки $з$ локальною областю на вході, i що нейрони цього шару можуть спільно використовувати параметри. Однак нейрони в обох шарах, не зважаючи на свої особливості, підраховують скалярний добуток, тому їх функціональна форма ідентична.

Наявність в ЗНМ шарів різного типу призводить до того, що для навчання нейронів цих шарів можуть використовуватися різні функції активації.

При вирішенні задачі класифікації до функції активації ставляться наступні вимоги:

1. Значення на виході з шару можуть трактуватися як ймовірність приналежності об'єкта заданому класу. Це означає, що кожне значення має бути в діапазоні від 0 до 1 , і сума всіх значень повинна дорівнювати одиниці.

2. Функція повинна бути диференційована, щоб можна було застосовувати градієнтні методи навчання нейронної мережі.

Внаслідок істотних позитивних властивостей для прихованих шарів буде використано функцію $\operatorname{ReLU}$. Для повнозв'язного шару використано функцію сигмоїда, яка виражається формулою (5):

$$
f(x)=\frac{1}{1+e^{-x}} .
$$

Вказану функцію активації зручно застосовувати для задачі класифікації, тому що вона дозволяє трактувати вихідні значення нейронів як ймовірність належності до даного класу. Рівень втрат останній рівень мережі, який відповідає за оновлення параметрів при іiі тренуванні. На цьому рівні за допомогою попередньо визначеної функції втрат вираховується різниця між справжніми значеннями тренувальних даних та результатами роботи мережі (прогнозом), після чого на наступному етапі тренування мережі ці дані використовуються для застосування алгоритмів тренування. Вибір та задання функції втрат є одним з найважливіших елементів побудови нейронної мережі, адже від цього значною мірою залежить як швидкість та якість тренування мережі, так і здатність мережі оцінювати точність отримуваних результатів. Значення функції втрат $є$ 
критерієм оцінки ефективності роботи мережі. В нашій моделі у якості функції витрат використаємо перехресну ентропію. Навчання ЗНМ аналогічно навчанню штучної мережі прямого поширення i складається в корекції іiї вагових параметрів на основі мінімізації обраної функції втрат. Для обчислення помилок у всіх шарах мережі і корекції іiі параметрів використовується метод зворотного поширення помилки. Навчання вагових коефіцієнтів $w_{i, j}(t)$ здійснюється алгоритмом стохастичного градієнтного спуску, що виражається наступною формулою (6):

$$
w_{i, j}(t+1)=w_{i, j}(t)+\eta \frac{\partial L}{\partial w_{i, j}},
$$

де $\eta$ - стала для регулювання величини поточного кроку;

\section{$L$ - функція втрат.}

Розглянемо детальну покрокову реалізацію запропонованої моделі згорткової нейронної мережі на мові програмування Python з використанням бібліотеки Keras. До переваг цієї бібліотеки слід віднести орієнтованість на нейронні мережі глибокого навчання, компактність, модульність та розширюваність. Keras $є$ прикладним програмним інтерфейсом рівня моделі, яка надає такі високорівневі будівельні блоки як шари, цільові функції, оптимізатори, обробники зображень. Окрім стандартних нейронних мереж бібліотека забезпечує підтримку згорткових мереж. Keras містить модель Sequential для формування лінійного стеку шарів. Вказану модель використаємо для побудови нашої згорткової нейронної мережі. Серед низки шарів згортки, представлених у Keras, виділимо Convolution2D. За допомогою цього шару здійснюється ефективна просторова згортка над зображеннями. Тому перший шар мережі - згортковий. Для нього в додатку було встановлено наступні параметри: розмір вхідних зображень $256 \times 256,32$ згорткові фільтри розміру $3 \times 3$. В якості функції активації в цьому та у всіх наступних згорткових шарах використано функцію ReLU. Шар MaxPooling2D бібліотеки Keras здійснює операцію максимальної підвибірки даних. В нашій моделі вказану операцію необхідно виконувати після операції згортки. Тому другий шар нашої мережі - шар підвибірки MaxPooling2D. Він має розмір блоку $2 \times 2$. Для ефективного розв'язку задачі в нашій згортковій нейронній мережі передбачимо ще 4 пари шарів згортки i підвибірки. Третій, п'ятий, сьомий, дев'ятий шари мережі - згорткові. Для цих шарів розмір фільтрів - $3 \times 3$, а кількість фільтрів дорівнює 32, 64, 64, 128 відповідно. Четвертий, шостий, восьмий, десятий шари - шари підвибірки 3 розміром блоку $2 \times 2$. Після створення ЗНМ з 10 шарів на наступному кроці дані перетворюються 3 двовимірно- го формату в одновимірний за допомогою шару Flatten. Для подальшого побудування моделі проведено регуляризацію методом Dropout зі значенням параметру 0.5. Наступний шар в мережі - повнозв'язний шар Dense, який складається з 512 нейронів. В цьому шарі в якості функції активації також використано ReLU. Наступний шар ЗНM - вихідний, який складається з одного нейрону. На відміну від попередніх шарів в ньому використовується функція активації сигмоїда. Фрагмент програмного коду, що реалізує побудування ЗНМ, наведено на рис. 7.

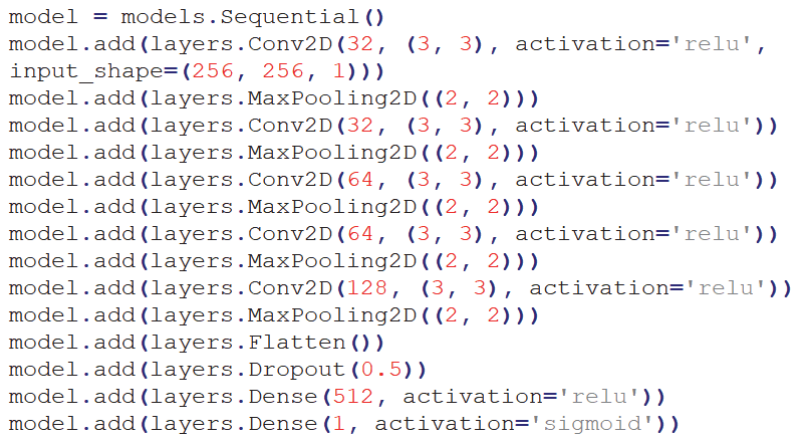

Рис.7. Фрагмент програмного коду з реалізацією моделі ЗНМ Джерело: розроблено автором.

На наступному кроці треба передбачити компіляцію розробленої мережі. При компіляції моделі в якості цільової функції використовуємо бінарну перехресну ентропію. Для оптимізації застосовано метод Rmsprop, а в якості метрики використовуємо точність. За допомогою методів класу ImageDataGenerator здійснюється ефективна попередня обробка зображень. Перед навчанням мережі всі зображення були перетворені в кольорову модель Grayscale, яка може передавати 256 відтінків сірого кольору або яскравості: значення 0 відповідає чорному кольору, а значення 255 - білому. Для завантаження зображень використано метод flow_from_directory Для навчання скомпільованої моделі нейронної мережі застосовано метод fit_generator. Параметр цієї функції еросhs визначає, скільки разів навчальний набір подавався моделі. В розробленому додатку кількість епох дорівнює 10 . Для зменшення загального часу і оптимізації навчання проводилося під керуванням операційної системи Linux. Для побудування графіків було використано математичну бібліотеку matplotlib. Застосовано іiі інтерфейс pyplot, що містить великій набір готових рішень. Графіки було побудовано шляхом послідовного виконання команд високого рівня.

На рис. 8 представлено результат обчислення точності побудованої моделі (номер епохи - за горизонтальною віссю, точність - за вертикальною). Точкова діаграма відповідає процесу на навчальній множині, а лінійна - на контрольній множині. 


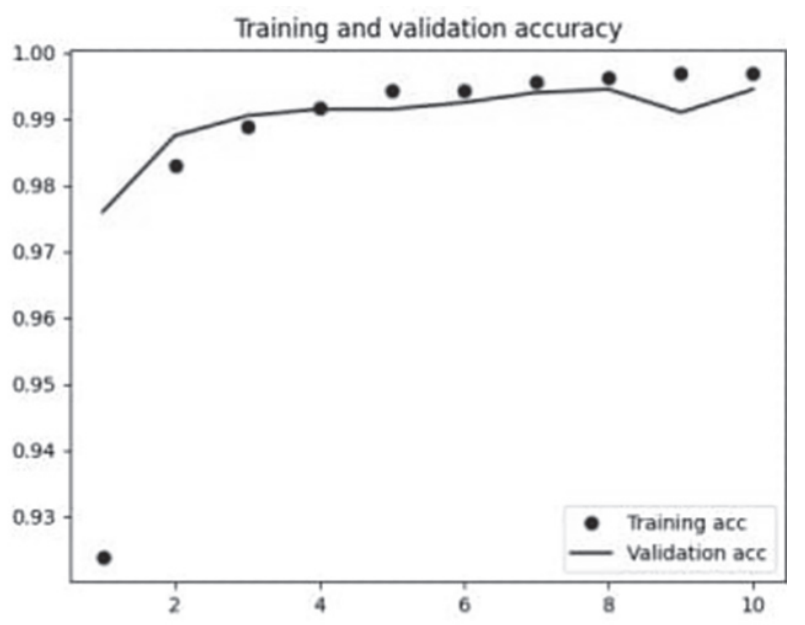

Рис. 8. Точність побудованої моделі Джерело: розроблено автором

На рис. 9 представлено результат обчислення функції втрат (номер епохи - за горизонтальною віссю, точність - за вертикальною). Точкова діаграма відповідає процесу на навчальній множині, а лінійна - на контрольній множині.

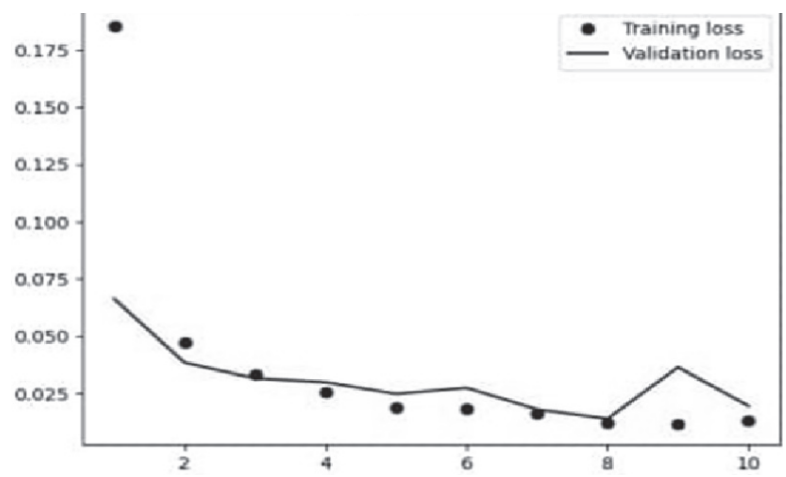

Рис. 9. Значення функції втрат Джерело: розроблено автором

Аналіз отриманих результатів, наведених в табл. 1, показує позитивну динаміку зростання показників точності як не тренувальній, так і на контрольній множинах.

Таблиця 1

Показники точності

\begin{tabular}{|c|c|c|}
\hline Номер епохи & $\begin{array}{c}\text { Точність на } \\
\text { тренувальній } \\
\text { множині }\end{array}$ & $\begin{array}{c}\text { Точність на } \\
\text { контрольній } \\
\text { множині }\end{array}$ \\
\hline 3 & 0.9889 & 0.9905 \\
\hline 4 & 0.9910 & 0.9915 \\
\hline 5 & 0.9942 & 0.9915 \\
\hline 6 & 0.9944 & 0.9925 \\
\hline 7 & 0.9955 & 0.9940 \\
\hline 8 & 0.9962 & 0.9945 \\
\hline 9 & 0.9960 & 0.9910 \\
\hline 10 & 0.9960 & 0.9945 \\
\hline
\end{tabular}

Результати роботи розробленого програмного додатку, наведені в табл. 1, виявили значне покращення показників точності розпочинаючи з четвертої епохи.
Аналіз отриманих результатів показує позитивну динаміку зростання показників функції витрат як не тренувальній, так і на контрольній множині.

Результати роботи програмного модулю системи, наведені в табл. 2, виявили значне покращення показників функції витрат розпочинаючи з четвертої епохи.

Таблиця 2

Показники функції витрат

\begin{tabular}{|c|c|c|}
\hline Номер епохи & $\begin{array}{c}\text { Значення } \\
\text { функції витрат } \\
\text { на тренувальній } \\
\text { множині }\end{array}$ & $\begin{array}{c}\text { Значення } \\
\text { функцї витрат } \\
\text { на контрольній } \\
\text { множині }\end{array}$ \\
\hline 3 & 0.332 & 0.316 \\
\hline 4 & 0.255 & 0.299 \\
\hline 5 & 0.0190 & 0.248 \\
\hline 6 & 0.0182 & 0.0275 \\
\hline 7 & 0.0164 & 0.0181 \\
\hline 8 & 0.0120 & 0.0140 \\
\hline 9 & 0.9960 & 0.9910 \\
\hline 10 & 0.9960 & 0.9945 \\
\hline
\end{tabular}

В окремому програмному модулі навчена ЗНМ використовується для визначення правильності надітої маски на певному зображенні, яке подається на обробку.

\section{Висновки}

Розроблено структуру штучної згорткової нейронної мережі визначення правильно носіння медичною маскою людини. Обгрунтовано побудування кожного елементу іiі структури. Запропоновано методику ії навчання. Розроблено програмний додаток на мові програмування Python. Отримано високі показники якості розпізнавання як на тренувальній (99,60\%), так і на контрольній множині $(99,45 \%)$. Ще одним досягненням побудованої моделі є мінімізація функції втрат: значення 0.0132 на тестовій множині і 0.0196 на тренувальній. Наукова новизна дослідження полягала у збільшенні розмірності карт ознак, що забезпечило оптимізацію моделювання згорткової нейронної мережі, збільшення швидкодії додатку. У порівнянні з моделями, запропонованими в роботах [7-10], розроблена система має кращу точність розпізнавання і більш просту архітектуру. Проведено успішне тестування працездатності додатку під різними апаратними і програмними конфігураціями. Тому навчена ЗНМ і програмний додаток можуть бути використаними під різними операційними системами. Розроблений додаток може бути застосований в галузях, що потребують контроля правильності носіння маски для підтримки безпеки під час пандемії.

В подальшому планується розробка згоркової нейронної мережі визначення виду маски. 


\section{Список літератури}

1. Mask or no mask for COVID-19: A public health and market study / T. Li, Y. Liu, M. Li, X. Qian, S.Y. Dai // PloS one. - 2020. - Vol. 15. - No. 8, e0237691. https://doi.org/10.1371/journal.pone.0237691.

2. Esposito S. To mask or not to mask children to overcome COVID-19 / S. Esposito, N. Principi // European journal of pediatrics. - 2020. - Vol.179. - No 8. - P. 1267-1270. https://doi.org/10.1007/s00431-020-03674-9.

3. A convolutional neural network decoder for convolutional codes / Z. Zhang, D. Yao, L. Xiong, B. Ai, S. Guo // International Conference on Communications and Networking in China. $-2019 . \quad-\quad$ P. 113-125. https://doi.org/doi.org/10.1007/978-3-030-41117-6_10.

4. Compressing convolutional neural networks via factorized convolutional filters / T. Li, B. Wu, Y. Yang, Y. Fan, Y. Zhang, W. Liu // Proceedings of the IEEE/CVF Conference on Computer Vision and Pattern Recognition. - 2019. P. 3977-3986. https://doi.org/10.1109/CVPR.2019.00410.

5. A Shallow Convolutional Neural Network for Apple Classification / J. Li, S. Xie, Z. Chen, H. Liu, J. Kang, Z. Fan, W. Li // IEEE Access. - 2020. - Vol. 8. - P. 111683-111692. https://doi.org/10.1109/ACCESS.2020.3002882.

6. Kadhim, M.A. Convolutional Neural Network for Satellite Image Classification / M.A. Kadhim, M.H. Abed // Asian Conference on Intelligent Information and Database Systems. - 2019. - P. 165-178. https://doi.org /10.1007/978-3-030-14132$5 \_13$.

7. Nieto-Rodríguez, A. System for medical mask detection in the operating room through facial attributes / A. NietoRodríguez, M. Mucientes, V.M. Brea // Iberian Conference on Pattern Recognition and Image Analysis. - 2015. - P. 138-145. https://doi.org/10.1007/978-3-319-19390-8_16.

8. Qin B. Identifying Facemask-Wearing Condition Using Image Super-Resolution with Classification Network to Prevent COVID-19 / B. Qin, D. Li // Sensors. - 2020. - Vol. 20(18). - P. 5236. https://doi.org /10.3390/S20185236.

9. Implementation of principal component analysis on masked and non-masked face recognition / M.S. Ejaz, M.R. Islam, M. Sifatullah, A. Sarker //2019 1st international conference on advances in science, engineering and robotics technology (ICASERT). - 2019. - P. 1-5. https://doi.org/10.1109/ICASERT.2019.8934543.

10. Meenpal T. Facial Mask Detection using Semantic Segmentation/ T. Meenpal, A. Balakrishnan, A. Verma // 2019 4th International Conference on Computing, Communications and Security (ICCCS). - 2019. - P. 1-5. https://doi.org/10.1109/CCCS.2019.8888092.

11. MaskedFace-Net - A dataset of correctly/incorrectly masked face images in the context of COVID-19/ A. Cabani, K. Hammoudi, H. Benhabiles, M. Melkemi // Smart Health. - 2021. - Vol. 19. - P. 100144. https://doi.org/10.1016/j.smhl.2020.100144.

12. Dropout with Tabu Strategy for Regularizing Deep Neural Networks. / Z. Ma, A. Sattar, J. Zhou, Q. Chen, K. Su // The Computer Journal. - 2020. - Vol. 63(7). - P. 1031-1038. https://doi.org/10.1093/COMJNL/BXZ062.

\section{References}

1. Li, T., Liu, Y., Li, M., Qian, X. and Dai, S.Y. (2020), Mask or no mask for COVID-19: A public health and market study, PloS one, Vol. 15, No. 8, e0237691. https://doi.org/10.1371/journal.pone.0237691.

2. Esposito, S. and Principi, N. (2020), To mask or not to mask children to overcome COVID-19, European journal of pediatrics, Vol. 179, No. 8, pp. 1267-1270. https://doi.org/10.1007/s00431-020-03674-9.

3. Zhang, Z., Yao, D., Xiong, L., Ai, B. and Guo, S. (2019), A convolutional neural network decoder for convolutional codes, International Conference on Communications and Networking in China, pp. 113-125. https://doi.org/10.1007/978-3-03041117-6 10 .

4. Li, T., Wu, B., Yang, Y., Fan, Y., Zhang, Y. and Liu, W. (2019), Compressing convolutional neural networks via factorized convolutional filters, Proceedings of the IEEE/CVF Conference on Computer Vision and Pattern Recognition, pp. 3977-3986. https://doi.org /10.1109/CVPR.2019.00410.

5. Li, J., Xie, S., Chen, Z., Liu, H., Kang, J., Fan, Z. and Li, W. (2020), A Shallow Convolutional Neural Network for Apple Classification, IEEE Access, Vol. 8. pp. 111683-111692. https://doi.org/10.1109/ACCESS.2020.3002882.

6. Kadhim, M.A. and Abed, M.H. (2019), Convolutional Neural Network for Satellite Image Classification, Asian Conference on Intelligent Information and Database Systems, pp. 165-178. https://doi.org /10.1007/978-3-030-14132-5_13.

7. Nieto-Rodríguez, A., Mucientes, M. and Brea, V.M. (2015), System for medical mask detection in the operating room through facial attributes, Iberian Conference on Pattern Recognition and Image Analysis, pp. 138-145. https://doi.org/10.1007/978-3-319-19390-8_16.

8. Qin, B. and Li, D. (2020), Identifying Facemask-Wearing Condition Using Image Super-Resolution with Classification Network to Prevent COVID-19, Sensors, Vol. 20(18), pp. 5236. https://doi.org /10.3390/S20185236.

9. Ejaz, M.S., Islam, M.R., Sifatullah, M. and Sarker, A. (2019), Implementation of principal component analysis on masked and non-masked face recognition, 2019 1st international conference on advances in science, engineering and robotics technology (ICASERT), pp. 1-5. https://doi.org/10.1109/ICASERT.2019.8934543.

10. Meenpal, T., Balakrishnan, A. and Verma, A. (2019), Facial mask detection using semantic segmentation, 2019 4th International Conference on Computing, Communications and Security (ICCCS), pp. 1-5. https://doi.org/10.1109/CCCS.2019.8888092.

11. Cabani, A., Hammoudi, K., Benhabiles, H. and Melkemi, M. (2021), MaskedFace-Net - A dataset of correctly/incorrectly masked face images in the context of COVID-19, Smart Health, Vol. 19, pp. 100144. https://doi.org/10.1016/j.smhl.2020.100144.

12. Ma, Z., Sattar, A., Zhou, J., Chen, Q. and Su, K. (2020), Dropout with Tabu Strategy for Regularizing Deep Neural Networks, The Computer Journal, Vol. 63(7), pp. 1031-1038. https://doi.org/10.1093/COMJNL/BXZ062. 


\section{Відомості про автора:}

Прочухан Дмитро Володимирович

викладач Харківського комп'ютерно-технологічного фахового коледжу Національного технічного університету “Харківський політехнічний інститут", Харків, Україна

https://orcid.org/0000-0002-4622-1015
Information about the author:

\section{Dmitriy Prochukhan}

Instructor of Kharkiv computer and technology professional college of National Technical University

"Kharkiv Polytechnic Institute",

Kharkiv, Ukraine

https://orcid.org/0000-0002-4622-1015

\title{
НЕЙРОСЕТЕВОЕ МОДЕЛИРОВАНИЕ В РЕАЛИЗАЦИИ СИСТЕМЫ ОПРЕДЕЛЕНИЯ ПРАВИЛЬНОСТИ НОШЕНИЯ МАСКИ
}

\section{Д.В. Прочухан}

Рассмотрена актуальная проблема правильности надевания медицинской маски у человека. Для ее решения предложено построение модели с использованием искусственного интеллекта. Рассмотрены механизмы классификации и обработки входных данных. Разработана структура сверточной нейронной сети в виде модели последовательной реализации слоев свертки, агрегирования, полной связи. Обоснована иелесообразность использования функиии ReLU для активачии узлов. Применен метод Drороит для предотвращения переобучения нейронной сети. Выходной слой реализован в виде одного нейрона с использованием функиии активаиии сигмоида. Оптимизаиия сверточной нейронной сети осуществлена методом стохастического градиентного спуска. Использован метод обратного распространения ошибки для обучения нейронной сети. Разработано программное приложение на языке программирования Руthоп. Использована библиотека Keras для обеспечения точности, правильности, полноты построенной модели. Проведено компиляиию с использованием бинарной перекрестной энтропии в качестве иелевой функиии. С помощью разработанного приложения проведено эффективное обучение сверточной нейронной сети на тестовых входных изображениях. Учитывая значительные требования к аппаратному обеспечению и программным ресурсам, этот прочесс был осуществлен под управлением операционной системы Lіпих. Ограниченное количество периодов обучения обеспечило уменьшение итогового времени обучения. Осуществлена проверка построенной системы на контрольном множестве. Получены высокие показатели распознавания изображений. Работоспособность программного приложения проверена с использованием различной аппаратной и программной конфигурации. Разработанная система может быть использованы в отраслях, требующих контроля выполнения правил безопасности во время пандемии.

Ключевые слова: сверточные нейронные сети, моделирование, искусственный интеллект, классификация.

\section{NEURAL NETWORK MODELING IN THE IMPLEMENTATION OF A SYSTEM FOR DETERMINATION THE CORRECT WEARING OF A MEDICAL MASK}

\author{
D. Prochukhan
}

The actual problem of the correctness of putting on a medical mask is reviewed. To solve it, the construction of a model using artificial intelligence is proposed. The mechanism of classification and input data processing is considered. The structure of convolutional neural network as a model of sequential implementation of convolution layers, aggregation and full connection is developed. The expediency of using ReLU function for node activation is substantiated. The Dropout method to prevent overfitting of the neural network is applied. The output layer is implemented as a single neuron using the sigmoid activation function. Optimization of the convolutional neural network is performed by stochastic gradient descent method. The method of error back propagation was used to train the neural network. A software application in the Python programming language is developed. Keras library is used to ensure accuracy, correctness, completeness of the built model. A compilation is performed using binary cross entropy as the target function. Using the developed application the effective training of convolutional neural network is carried out on test input images. Despite the significant hardware and software resource requirements, this process is passed under the Linux operating system. A limited number of training periods ensures that the final training time was reduced. The constructed system is tested on the control set. High rates of image recognition are obtained. The functionality of the software application is tested using various hardware and software configurations. The developed system can be used in industries requiring pandemic safety control.

Keywords: convolutional neural networks, modeling, artificial intelligence, classification. 